\title{
Kekerasan terhadap Anak dalam Panti Sosial Asuhan Anak
}

\author{
Ismet Firdaus
}

\begin{abstract}
Abstrak
Violence against children in Indonesia continues to increase. Many cases of violence, one of them, as happened at the childcare institution (orphanage). Forms of violence and crime are physical, psychological, sexual, and neglect. Results of the study conducted by Ministry of Social Affairs, UNICEF, and Save the Children showed that the factors that support the physical and psychological violence to the children are associated with the method in educating and disciplining children. Often used physical force or by means of humiliating and degrading treatment of children. Ironically, the staff and caregivers view it as an important part of their role in doing the job.
\end{abstract}

Key words: kekerasan, kekerasan terhadap anak, kejahatan kekerasan.

\section{Pendahuluan}

"Saya dipukul pakai bambu hingga membekas," kata Yd sembari memperlihatkan bekas luka di punggung dan kakinya. Sedangkan $\mathrm{Hr}$ mengaku pernah dipukul sambil dikejar dari lantai 1 hingga lantai 3 sampai-sampai buang air. "Teman saya ada yang pernah digantung di tangga yang mengakibatkan kepalanya bocor," kata Hr, korban kekerasan di salah suatu panti asuhan di Gowa, Kota Makasar. (Disiksa, 20 Anak Panti Melapor ke Polisi, diunduh dari www.tempo interaktif. com, 12 Juli 2011).

Pemberitaan media elektronik tersebut merupakan salah satu potret beberapa kasus kekerasan pada anak. Menurut data pelanggaran hak anak yang dikumpulkan Komisi Nasional Perlindungan Anak dari data induk lembaga perlindungan anak di 30 provinsi di Indonesia, pada tahun 2006 jumlah kasus pelanggaran hak anak yang terpantau sebanyak 13.447.921 kasus dan pada 2007 jumlahnya meningkat 40.398.625 kasus. Di samping itu, Komnas Anak juga melaporkan bahwa selama periode Januari-Juni 2008 sebanyak 12.726 anak menjadi korban kekerasan seksual dari orang terdekat mereka seperti orang tua kandung/tiri/angkat, guru, paman, kakek dan tetangga (Liunir Z, 2010: 1)

Kekerasan ditemukan di dalam keluarga, sekolah, panti atau institusi dan tempat lain yang menjadi tempat perawatan, jalanan, tempat kerja dan penjara. Kekerasan dapat timbul karena keyakinan budaya, norma-norma, dan praktik-praktik tradisi atau karena keadaan konflik. Sebagian kecil kekerasan terhadap anak berakibat pada kematian, namun sebagian besar tidak meninggalkan bekas-bekas yang kasat mata. Meskipun demikian, kekerasan merupakan masalah serius yang menimpa anak-anak saat ini. Banyak kekerasan yang disembunyikan. Anak-anak tidak melaporkan tindakan tersebut karena ketakutan akan balasan yang akan dilakukan pelaku kekerasan terhadap mereka.

Baik anak maupun pelaku kekerasan mungkin tidak menganggap bahwa yang dilakukan itu merupakan kekerasan, tapi memandang sebagai hukuman yang bisa dibenarkan dan perlu. Anak sebagai korban merasa malu atau bersalah, dan percaya bahwa mereka memang sepantasnya mendapatkan perlakuan demikian. Oleh karena itu, mereka tidak mau mengungkapkan apa yang terjadi. (O’Donnel, 2006: 95). 
Kenakalan sering menjadi penyebab kemarahan orang tua, pengurus panti atau guru sehingga anak menerima hukuman. Bahkan karena disertai emosi, tidak jarang digunakan kekerasan fisik. Apabila hal ini terus dialami oleh anak, maka akan menimbulkan luka yang mendalam pada fisik dan batinnya, sehingga tumbuh kebencian pada mereka dan menyebabkan trauma.

Akibat lain dari kekerasan anak adalah merasa rendah harga dirinya karena menganggap pantas mendapat hukuman, prestasinya di sekolah atau hubungan sosial lainnya juga menurun, dan pergaulan dengan teman-temannya menjadi terganggu. Semua itu akan mempengaruhi rasa percaya diri anak yang sejatinya harus dibangun sejak kecil. Lebih jauh, apa yang dialami akan membuatnya meniru kekerasan dan bertingkah laku agresif dengan cara memukul atau membentak bila timbul rasa kesal di dalam dirinya. Anak akan selalu cemas, mengalami mimpi buruk, depresi atau masalah-masalah di sekolah.

Sedangkan untuk konteks remaja, setiap remaja yang terbunuh dengan cara kekerasan, 20 sampai $40 \%$ mengalami cedera yang cukup serius sehingga memerlukan perawatan rumah sakit. Efek kekerasan dapat berlangsung selama berbulan-bulan atau bertahun-tahun, bahkan bisa menjadi cacat menetap. Selain cedera fisik, para korban beresiko mengalami masalah psikologis dan perilaku seperti depresi, penyalahgunaan alkohol, kecemasan, dan perilaku yang mengarah pada bunuh diri.

Makalah ini mencoba menelaah tentang konsep kekerasasan, kejahatan kekerasan dan menganalisis bentuk-bentuk kekerasan terhadap anak dalam panti asuhan anak di Indonesia.

\section{Definisi Kekerasan, Kekerasan terhadap Anak, dan Kejahatan Kekerasan}

\section{a. Kekerasan}

Kekerasan sebagai salah satu bentuk agresi, memiliki definisi yang beragam meski secara sepintas setiap orang sering mendengar dan memahaminya.

Arti kekerasan dalam Kamus Besar Bahasa Indonesia (1998: 733) adalah perihal (yang bersifat/berciri) keras; perbuatan seseorang atau sekelompok orang yang menyebabkan cedera atau matinya orang lain atau menyebabkan kerusakan fisik atau barang orang lain; dan paksaan. Dapat dikatakan bahwa kata kekerasan dalam bahasa Indonesia umumnya dipahami hanya menyangkut serangan fisik belaka. Jadi tindakan kekerasan (perbuatan yang menyebabkan cedera, luka, mati atau kerusakan) sangat dekat dengan perbuatan yang mengandung sifat penyiksaan (torture) dan pengenaan penderitaan atau rasa sakit yang sangat berat (severe pain or suffering) (Barda Nawawi Arief, 1998: 20)

Kekerasan menurut KUHP hanya didefinisikan sebagai kekerasan fisik sebagaimana yang terdapat dalam Pasal 89 dan Pasal 90 KUHP. Pasal tersebut mengemukakan bahwa yang dimaksud dengan melakukan kekerasan adalah membuat orang jadi pingsan atau tidak berdaya lagi. Dalam penjelasan pasal itu kemudian dinyatakan bahwa melakukan kekerasan ialah menggunakan tenaga atau kekuatan jasmani sekuat mungkin secara tidak sah, misalnya memukul dengan tangan atau dengan segala macam senjata, menyepak, menendang dan sebagainya yang menyebabkan orang yang terkena tindakan itu sakit yang sangat.

Dalam pasal tersebut, melakukan kekerasan sama dengan membuat orang pingsan atau tidak berdaya. Pingsan artinya hilang ingatan atau tidak sadar akan dirinya. Tidak berdaya 
artinya tidak mempunyai kekuatan atau tenaga sama sekali, sehingga tidak mampu mengadakan perlawanan sedikit pun, seperti orang yang diikat dengan tali pada kaki dan tangannya, orang lumpuh yang terkurung dalam kamar karena terkena suntikan. Orang yang tidak berdaya ini masih dapat mengetahui apa yang terjadi atas dirinya (R. Suhandhi, 1981: 107). Sedangkan Pasal 90 KUHP menentukan bahwa yang dimaksud dengan luka berat adalah:

a. Penyakit atau luka yang tak dapat diharapkan akan sembuh lagi dengan sempurna atau yang dapat mendatangkan bahaya maut.

b. Senantiasa tidakcakap mengerjakan pekerjaan jabatan atau pekerjaan pencaharian.

c. Tidak dapat lagi memakai salah satu panca indera.

d. Mendapat cacat besar.

e. Lumpuh (kelumpuhan).

f. Akal (tenaga paham) tidak sempurna lebih dari empat minggu.

g. Gugur atau matinya kandungan seorang perempuan.

Definisi kekerasan dari kedua pasal di atas hanya menyangkut kekerasan fisik saja yang berakibat luka pada badan atau fisik, tidak meliputi kekerasan lainnya seperti psikis, seksual, dan ekonomi sesuai dengan Deklarasi PBB tentang anti kekerasan.

\section{b. Kekerasan terhadap Anak (Child abuse)}

Menurut Komisi Nasional Perlindungan Anak, kekerasan terhadap anak adalah segala bentuk perbuatan atau tindakan terhadap anak yang berakibat timbulnya kesengsaraan atau penderitaan secara fisik, seksual, psikis, mental, emosi dan penelantaran termasuk pemaksaaan dan merendahkan martabat. Penelantaran anak (child neglect) merupakan konsep yang luas yang meliputi kegagalan memenuhi kebutuhan emosi, kebutuhan materi anak dan kegagalan menyediakan stimulasi fisik dan stimulasi intelektual serta pengawasan dan bimbingan. Pengawasan yang tidak memadai dapat mengarah pada penyebab kematian dan cedera karena kecelakaan yang terjadi di rumah, memberi andil terhadap keterlibatan anak dalam kegiatan berbahaya seperti penggunaan obat-obat terlarang, kegiatan seks yang prematur dan tidak amam, dan sebagainya.

WHO melaporkan bahwa sekitar 400.000 anak-anak yang berusia di bawah 5 tahun meninggal dunia setiap tahunnya karena kecelakaan-kecelakaan seperti tenggelam, terbakar, keracunan, dan kecelakaan lalulintas. Data dari Amerika Serikat menunjukkan bahwa penelantaran menyebabkan lebih banyak kematian pada anak di bawah usia delapan belas tahun bila dibandingkan dengan kekerasan. Penelantaran adalah bentuk paling ekstrim dari pengabaian. Keputusan untuk menelantarkan seorang anak kadang-kadang merupakan tanggapan terhadap buruknya mekanisme dukungan (support mechanism) atau beratnya tradisi budaya.

Di Indonesia, anak-anak ditelantarkan karena orang tua tidak sanggup memberikan nafkah kepada mereka, sehingga menyerahkan anak ke keluarga atau panti yang memiliki kemampuan ekonomi lebih mapan. Orang tua mereka seolah percaya bahwa itu merupakan satu-satunya cara untuk menawarkan kesempatan kepada anak agar memperoleh masa depan lebih baik. Data paling mengejutkan, pada beberapa budaya, stigma yang ditimpakan kepada kehamilan di luar perkawinan menyebabkan sebagian besar anak yang lahir di luar perkawinan ditelantarkan pada waktu dilahirkan (O’Donnel, 2006: 100). 


\section{c. Kejahatan Kekerasan}

Kitab Undang-Undang Hukum Pidana (KUHP) merumuskan kejahatan kekerasan ke dalam berbagai pasal yaitu 285-301 (kejahatan susila), 310-321 (penistaan), 324-337 (penghilangan kemerdekaan), 338-340 (pembunuhan), 351-356 (penganiayaan), dan lainlain. Sedangkan pengertian kejahatan kekerasan itu sendiri dalam KUHP tidak diberikan definisinya.

Ada beberapa pendapat dari para sarjana yang memberikan definisi tentang kejahatan kekerasan. Menurut Huriodo (1984: 4), kejahatan kekerasan adalah:

a. Tindak pidana yang didahului, disertai atau dikuti dengan kekerasan terhadap orang dengan obyek kejahatan berupa barang atau orang (dengan sengaja untuk mendapatkan barang orang lain secara tidak sah atau mencederai dan atau membunuh orang).

b. Suatu tindak pidana sebagaimana yang disebut dalam Pasal 89 KUHP, yaitu perbuatan yang membuat orang menjadi pingsan atau tidak berdaya, maka perbuatan itu bersifat fisik.

c. Tindak pidana yang bersifat psikis, sehinga menyebabkan orang lain tidak berdaya

Sedangkan ketentuan pidana kejahatan kekerasan terhadap anak dalam UU No. 23 tahun 2003 tentang perlindungan anak sebagai berikut:

1. Pasal 77 menyatakan bahwa setiap orang yang dengan sengaja melakukan tindakan diskriminasi terhadap anak yang mengakibatkan anak mengalami kerugian, baik materiil maupun moril, sehingga menghambat fungsi sosialnya atau penelantaran terhadap anak yang mengakibatkan anak mengalami sakit atau penderitaan, baik fisik, mental, maupun sosial, dipidana dengan pidana penjara paling lama 5 (lima) tahun dan/atau denda paling banyak Rp 100.000.000,00 (seratus juta rupiah).

2. Pasal 78 bahwa setiap orang yang mengetahui dan sengaja membiarkan anak dalam situasi darurat sebagaimana dimaksud dalam Pasal 60, anak yang berhadapan dengan hukum, anak dari kelompok minoritas dan terisolasi, anak yang tereksploitasi secara ekonomi dan/atau seksual, anak yang diperdagangkan, anak yang menjadi korban penyalahgunaan narkotika, alkohol, psikotropika, dan zat adiktif lainnya (napza), anak korban penculikan, anak korban perdagangan, atau anak korban kekerasan sebagaimana dimaksud dalam Pasal 59, padahal anak tersebut memerlukan pertolongan dan harus dibantu, dipidana dengan pidana penjara paling lama 5 (lima) tahun dan/atau denda paling banyak Rp. 100.000.000,00 (seratus juta rupiah).

3. Pasal 79 bahwa setiap orang yang melakukan pengangkatan anak yang bertentangan dengan ketentuan sebagaimana dimaksud dalam Pasal 39 ayat (1), ayat (2), dan ayat (4), dipidana dengan pidana penjara paling lama 5 (lima) tahun dan/atau denda paling banyak Rp 100.000.000,00 (seratus juta rupiah).

4. Pasal 80 menyatakan bahwa: (1) setiap orang yang melakukan kekejaman, kekerasan atau ancaman kekerasan, atau penganiayaan terhadap anak, dipidana dengan pidana penjara paling lama 3 (tiga) tahun 6 (enam) bulan dan/atau denda 
paling banyak Rp 72.000.000,00 (tujuh puluh dua juta rupiah); (2) dalam hal anak sebagaimana dimaksud dalam ayat (1) luka berat, maka pelaku dipidana dengan pidana penjara paling lama 5 (lima) tahun dan/atau denda paling banyak Rp 100.000.000,00 (seratus juta rupiah); (3) dalam hal anak sebagaimana dimaksud dalam ayat (2) mati, maka pelaku dipidana dengan pidana penjara paling lama 10 (sepuluh) tahun dan/atau denda paling banyak Rp 200.000.000,00 (dua ratus juta rupiah); (4) pidana ditambah sepertiga dari ketentuan sebagaimana dimaksud dalam ayat (1), ayat (2), dan ayat (3) apabila yang melakukan penganiayaan tersebut orang tuanya.

5. Pasal 81 menyatakan bahwa: (1) setiap orang yang dengan sengaja melakukan kekerasan atau ancaman kekerasan, memaksa anak melakukan persetubuhan dengannya atau dengan orang lain, dipidana dengan pidana penjara paling lama 15 (lima belas) tahun dan paling singkat 3 (tiga) tahun dan denda paling banyak Rp 300.000.000,00 (tiga ratus juta rupiah) dan paling sedikit Rp 60.000.000,00 (enam puluh juta rupiah); (2) ketentuan pidana sebagaimana dimaksud dalam ayat (1) berlaku pula bagi setiap orang yang dengan sengaja melakukan tipu muslihat, serangkaian kebohongan, atau membujuk anak melakukan persetubuhan dengannya atau dengan orang lain.

6. Pasal 82 bahwa setiap orang yang dengan sengaja melakukan kekerasan atau ancaman kekerasan, memaksa, melakukan tipu muslihat, serangkaian kebohongan, atau membujuk anak untuk melakukan atau membiarkan dilakukan perbuatan cabul, dipidana dengan pidana penjara paling lama 15 (lima belas) tahun dan paling singkat 3 (tiga) tahun dan denda paling banyak Rp 300.000.000,00 (tiga ratus juta rupiah) dan paling sedikit Rp 60.000.000,00 (enam puluh juta rupiah).

\section{Bentuk-bentuk Kekerasan dan Kejahatan Kekerasan yang Dialami Anak Panti di Indonesia}

Hasil penelitian Kementerian Sosial, Unicef, Save the Children (1996: 170-194) menunjukkan terjadinya kekerasan fisik dan psikis di Panti Asuhan Anak, yakni:

\section{a. Kekerasan Fisik ${ }^{1}$ dan Psikis $^{2}$}

"Dua penghuni Wisma UPS Asuhan Anak Nganjuk yaitu, Ris (12) dan Bi (14) nekat kabur karena tidak tahan. Kasus dugaan kekerasan itu pun saat ini tengah ditangani pihak yang berwajib, setelah kedua orang tua korban melapor pada polisi. Menurut keterangan Mujianah (38), ibu Ris asal Begandung, Nganjuk mengaku terkejut saat anaknya pulang dengan cara kabur dari panti, pada hari Kamis lalu. "Ris mengaku sedang sakit akibat kekerasan yang dilakukan oleh para seniornya. Ris langsung

${ }^{1}$ Dalarn Pasal 1 Ayat (1) Draft Rancangan Undang-Undang Anti Kekerasan Dalam Rumah Tangga kekerasan fisik adalah tiap-tiap sikap dan perbuatan yang mengakibatkan rasa sakit, cedera, luka atau cacat pada tubuh seseorang,dan atau sampai menyebabkan kematian;

2 Dalarn Pasal 1 Ayat (1) Draft Rancangan Undang-Undang Anti Kekerasan Dalam Rumah Tangga kekerasan psikis adalah tiap-tiap sikap dan perbuatan yang mengakibatkan ketakutan, hilangnya rasa percaya diri, hilangnya kemampuan untuk bertindak, rasa tidak berdaya, dan atau sampai menderita psikis berat. 
dibawa ke rumah sakit untuk menjalani visum. Berdasar keterangan dokter, Ris mengalami luka memar dibagian dalam“ (koranmontera.com).

Menurut pengakuan Kepala Panti Nurul Ikhlas, kekerasan yang sering terjadi di lingkungan panti berupa perkelahian antar anak, terutama anak laki-laki, sedangkan anak perempuan paling hanya adu mulut. Meskipun ada anggapan umum pada staf maupun anakanak bahwa tidak ada kekerasan di panti kecuali beberapa contoh perkelahian antar anak, namun ketika penelitian ini lebih lanjut menanyakan apakah ada yang pernah dipukul maka gambaran berbeda tiba-tiba muncul.

Kasus di Panti Asuhan Darul Aitam, NTB, merupakan contoh yang cukup menarik dalam hal ini. Berdasarkan pengakuan salah satu korban kekerasan menyatakan, "Kami biasa dipukul kalau tidak naik musholla, tidak kerja. Pokoknya kalau melanggar aturan pasti dikasih hukuman. Tidak boleh sarapan pagi, kalau berturut-turut bisa dibotakin. Nohnoh si dia dibotakin karena sering tidak naik musholla. Kalau pacaran atau mencuri maka hukumannya tidak ada ampun, langsung dikeluarin," katanya.

Hukuman fisik dan psikologis ditemukan di mayoritas panti asuhan. Hal ini sering bersifat rutin dan tanpak pengurus serta anak-anak menganggap sebagai bagian dari kehidupan seharihari mereka. Hal ini juga secara umum tidak dianggap oleh mereka sebagai kekerasan, seperti diceritakan oleh seorang anak dari Harapan di NTB. Menurutnya, kekerasan itu tidak ada, yang ada hanyalah semacam sanksi karena anak-anak melanggar aturan. Di antaranya hukuman scout jump atau push up oleh pengasuh karena tidak ikut sholat jama'ah atau tidak piket.

Sebagai suatu cara untuk mendidik dan mendisiplinkan anak, penggunaan pemaksaan fisik dan perlakuan mempermalukan atau merendahkan banyak digunakan secara luas. Banyak pula staf yang memandang itu sebagai bagian penting dari peranan mereka. Pada kenyataannya, seperti yang kita lihat di atas, sama halnya dengan mengatur jadwal harian dan memantau anak, mendisiplinkan anak dipandang sebagai peranan utama dari para pengasuh.

Keyakinan pada kebutuhan mendisiplinkan anak dipandang sebagai peranan utama dari para pengasuh. Keyakinan pada kebutuhan mendisiplinkan anak dengan paksa, tampak disetujui oleh kebanyakan staf meski tidak banyak mengungkapkan secara terbuka, seperti yang dikatakan seorang mantan staf pengasuh di Panti Muhammadiyah Lhoksemawe, "Anak Aceh itu keras, tidak bisa dilembutin tapi harus dikerasin. Kalau tidak dikerasin maka aturan tidak jalan, sehingga anak perlu dijewer, dicubit, dipukul atau ditampar. Apalagi bagi yang sudah gede. Jika keseringan keluar malam, saya tidak sanggup lagi, saya serahin ke kepala panti dan pengasuh yang lain," akunya.

Bentuk kekerasan dalam konteks disiplin atau mendidik anak bervariasi seperti meninju, melempar, memukul dengan kayu atau batang rotan, mencubit perut, menjewer telinga, merayap di lumpur, menyuruh lari mengelilingi lapangan, rolling, menyuruh mengangkat barang yang berat, berjemur, melakukan push up atau scout jump, menyiramkan air kotor, membotaki di muka umum, dan mengunci di WC, dan beberapa bentuk pengucilan. Umumnya, semakin serius pelanggaran dilakukan atau semakin dianggap "nakal" seorang anak, hukumannya akan semakin berat.

Menariknya, meninju kadang dilihat sebagai hal yang dekat dengan kekerasan di beberapa kasus dan tidak dapat diterima. Sedangkan semua bentuk pemukulan lainnya 
dipandang hanya sebagai hukuman dan tidak sama dengan kekerasan. Mencubit perut anak atau memukul dengan rotan merupakan bentuk umum hukuman, sementara membotaki dan menyiramkan air kotor dilakukan pada anak yang melakukan pelanggaran berulang-ulang. Beberapa pengalaman anak-anak panti Nurul Ikhlas yang mengalami kekerasan dari pengasuh A10 (perempuan, kelas 6 SD, 15 tahun) dipukul kakinya dengan rotan, dicubit pahanya hingga biru, dan dimarahi. Hukuman tersebut diterima A10 karena kesiangan mengambil jatah makan. Akibatnya, jika terlambat mengambil jatah makan, kadang-kadang terpaksa tidak makan. Ini sebagaimana diungkapkannya, "Separuh makan separuh tidak". Demikian pula dengan A9 (perempuan, kelas 2 SMP, 14 tahun). Dia dimarahi dan dipukul dengan rotan karena telat mengambil jatah makan. Tidak jauh beda dengan itu, A8 (perempuan, kelas I MAN, 16 tahun) juga mengalami perlakuan yang sama.

Di sebagian besar kasus, hukuman diterapkan oleh kepala panti atau staf. Tetapi di sejumlah kecil panti, anak-anak juga dihukum secara kolektif karena kesalahan satu orang. Perlakuan ini tampaknya dipraktikkan untuk memastikan semua anak merasakan hukuman. Di satu panti milik pemerintah terdapat contoh mengenai praktik ini.

"Setahun yang lalu seorang anak perempuan (A6) kelas I SMA, menginap di rumah kawan tanpa izin. Pulangnya dia terkena marah pengasuh. Malamnya, sebelum makan di mana anakanak sedang berkumpul di dapur, atas perintah staf I, teman-teman sekelas anak tersebut yang ada di panti diminta mencubit anak tersebut ditambah cubitan dari teman seagamanya (Katholik). Cubitan tersebut dilakukan di depan anak-anak dan pengasuh. Saat itu, dia jatuh pingsan namun dibiarkan (anak-anak tidak selera makan, tapi dipaksa). Banyak anak yang menangis menyaksikan perbuatan tersebut sehingga juga dimarahi. Akibatnya, setelah makan A6 masuk kamar mengunci pintu lalu mengambil gunting untuk bunuh diri. Kebetulan ada temannya di dalam kamar, sehingga dengan tangkas gunting itu diambil, meski tangan A6 sudah terluka".

Di beberapa panti di mana tidak cukup terdapat orang dewasa untuk mengawasi, anak yang paling tua akan diminta untuk mendisiplinkan yang lebih muda. Contohnya Panti Muhammadiyah, Meulaboh. Akibat tidak ada pengasuh yang jelas di asrama putera, pelaksanaan hukuman diberikan kepada anak usia SMA dan mahasiswa. Hukumannya berbentuk pukulan yang diberlakukan pada adik-adik asuh, anak laki-laki.

Di Panti Yoga Dharma, Jawa Tengah, anak-anak kerap mendapat ejekan dari temantemannya di sekolah. Mereka dianggap kuper (kurang pergaulan), ndeso (kampungan), orang miskin sehingga kalau menggunakan barang yang pantas pasti syirik. Dalam bahasa mereka, "cah panti koq ngono, biasane cah panti ya koyo ngono."

\section{b. Kekerasan Seksual ${ }^{3}$}

Pada tahun 2004 di satu panti di Kalimantan Barat, ditemukan sebuah kasus kekerasan seksual yang melibatkan dua anak dari panti yang sama. Hal yang cukup menarik adalah bukan para pengasuh melainkan guru di sekolah yang mengetahui apa yang terjadi. Sebuah kasus kekerasan seksual terjadi di panti ini tahun 2004, melibatkan seorang anak laki-laki yang duduk dibangku kelas 3 SMP dan seorang anak perempuan yang baru duduk di kelas 5 SD.

${ }^{3}$ Dalarn Pasal 1 Ayat (1) Draft Rancangan Undang-Undang Anti Kekerasan Dalam Rumah Tangga, kekerasan seksual adalah tiap-tiap sikap dan perbuatan yang ditujukan terhadap tubuh atau seksualitas seseorang untuk tujuan merendahkan martabat serta integritas tubuh atau seksualitasnya, yang berdampak secara fisik maupun psikis. 
Begitu pula, kasus di panti X pada awal pendirian tahun 1990an diketahui terjadi kasus seorang staf memperkosa dan membuat hamil salah seorang anak perempuan asuhannya. Akibatnya, pengasuh itu dipenjara dengan hukuman selama kurang lebih 3 tahun. Setelah kejadian tersebut, mulai terjadi krisis kepercayaan di masyarakat. Masyarakat sudah tidak percaya lagi terhadap panti tersebut sehingga satu per satu anak diambil oleh orang tua atau walinya. Akhirnya pada tahun 1998, panti asuhan ini resmi ditutup.

\section{Penutup}

Beberapa kasus di atas menunjukkan bahwa kekerasan yang dialami anak di panti asuhan anak, baik milik pemerintah maupun swasta sudah merupakan kategori kejahatan kekerasan. Hasil penelitian Save The Children, Depsos dan UNICEF sebagian menunjukkan bahwa hal yang mendukung terjadinya kekerasan fisik dan psikis tersebut berkaitan dengan cara panti asuhan mendidik dan mendisiplinkan anak. Kerapkali digunakan pemaksaan fisik dan perlakuan yang mempermalukan atau merendahkan anak (pelembagaan kekerasan). Staf dan pengasuh panti asuhan memandang hal tersebut sebagai bagian penting dari peranan mereka dalam melakukan pekerjaannya. 


\section{Bibliografi}

Arief, Barda Nawawi, Beberapa Aspek Kebijakan Penegakan dan Pengembangan Hukum Pidana. Bandung: Citra Aditya Bakti, 1998.

Huriodo, "Penegakan Hukum Dalam Rangka Penanggulangan Kejahatan Kekerasan di Wilayah Perkotaan", makalah disampaikan dalam Seminar Kriminalogi, FISIP UI, 29 November 1984.

Liunir, Z , Kekerasan terhadap anak: Permasalahan dan Pemecahannya. Jakarta: tnp 2010. O’Donnel, Dan, Perlindungan Anak, Sebuah Panduan bagi Anggota Dewan Perwakilan Rakyat. Jakarta: UNICEF, 2006.

Suhandhi, R, KUHP dan Penjelasannya. Surabaya: Usaha Nasional, 1981.

Save the Children, DEPSOS RI, dan UNICEF, Seseorangyang Berguna: Kualitas Pengasuhan di Panti Sosial Asuhan di Indonesia. Jakarta: UNICEF, 2007.

Tim Penyusun Kamus Pusat Pembinaan dan Pengembangan Bahasa, Kamus Besar Bahasa Indonesia. Jakarta: Balai Pustaka, 1998

UU No. 23 tahun 2003 Tentang Perlindungan Anak.

www.tempointeraktif.com, "Disiksa, 20 Anak Panti Melapor ke Polisi,” Selasa, 12 Juli 2011. 